\title{
Study of starter cultures in biotechnology of medical and preventive nutrition products
}

\author{
Ekaterina Reshetnik ${ }^{1}$, Yulia Derzhapolskaya ${ }^{1}$, and Svetlana Gribanova ${ }^{1, *}$ \\ ${ }^{1}$ Far Eastern State Agrarian University ,86, Politeknicheskaya Str., Blagoveschensk, Russia
}

\begin{abstract}
The article presents the results of research on the quality of Lavitol - B premix in accordance with the requirements of regulatory and technical documentation, two versions of starter cultures with different strain ratios of cultures and their impact on the quality of fermented milk products for preventive nutrition. During the research, the quality and safety indicators of the Lavitol-b premix were studied. The data on the effect of form and ratios of starter cultures on the fermentation process and increase of biomass of lactic acid microorganisms and bifidobacteria, it was found titratable acidity of samples and duration of ripening. The carbohydrate composition of the obtained samples of fermented milk products was studied.
\end{abstract}

\section{Introduction}

World experience shows an increased interest in a healthy lifestyle, including in Russia. Today, a healthy lifestyle is not only sports, but also a healthy diet, that is, the systematic use of specialized functional products enriched with biologically active ingredients that help to maintain the normal functioning of the human body $[1,2]$.

Currently, one of the priority socio-economic tasks is to develop and expand the line of functional products that will be products of daily demand and will have a positive impact on the human body if constantly consumed as part of the diet [3].

One of the rational ways to solve this problem is to expand the range and develop technology for new types of fermented milk products for therapeutic and preventive nutrition. Dairy products in health and diets according to their functional properties superior to milk because they contain all the constituent parts of milk into a more digestible form [4, 5].

Dairy products affect the secretory activity of the stomach and promotes rapid release of enzymes that accelerate the process of digestion and normalize bowel $[6,7]$.

Biotechnological processes are the basis for the production of fermented milk products. The choice of starter depends on the organoleptic and rheological properties of the finished product. The main component of starter cultures for all dairy products are lactic acid bacteria, which during the fermentation process transformerait lactose, proteins, salts and other components of milk in the aroma and flavor compounds, causing sensory

*Corresponding author: 1sv24leon@mail.ru 
characteristics and inhibiting the development of pathogenic microflora in the formation of lactic acid and reduce the $\mathrm{pH}[8,9]$.

It is also known that starter cultures with a combined composition have a higher activity and resistance to negative environmental factors compared to single-stem starter cultures [10].

When developing the technology of fermented milk drinks for therapeutic and preventive nutrition, starter cultures were selected taking into account their biotechnological properties. So there is evidence that most of the lactic acid streptococci has lactobacilius ability of thermophilic lactic acid Streptococcus. Using Str. thermophilus as part of the starter culture will allow more active hydrolysis of milk lactose. As pure cultures of Str. thermophilus ferments glucose glycolytically to form the 1 and D isomer of lactic acid, thereby contributing to a decrease in its content in the finished product, which gives the product therapeutic and preventive properties [11-13].

As a biologically active additive in the production of fermented milk products, the premix Lavitol-B can be used, which is a mixture in a ratio of 1:3 of the flavonoids Lavitol (dihydroquercetin) and polysaccharide — arabinogalactan.

According to its chemical properties, dihydroquercetin is an active antioxidant that can inhibit oxidative reactions, while the level of antioxidant activity allows it to be placed in the first position among substances with a similar spectrum of action. As a substance with a high degree of biological activity, dihydroquercetin has a whole range of positive effects on the metabolic reactions and dynamics of various pathological processes in humans. Over the past decades, dihydroquercetin has been well studied due to its unique biological properties [14].

Dihydroquercetin was discovered as part of phenolic complexes derived from numerous plant extracts. Dihydroquercetin belongs to phenolic compounds (polyphenols), a group of secondary metabolites of biochemical processes occurring in plant organisms, the so-called group of flavonides, signaling molecules involved in the chain of biosynthesis that have the properties of antioxidants. It is a second line (secondary metabolites) of plant protection from the effects of the environment, living organisms. The biological activity of the dihydroquercetin molecule is due to its native, i.e. natural, form, thanks to which the molecule fulfills its biological purpose.

Arabinogalactan is a water-soluble polysaccharide of plant origin obtained from the Daurian larch tree. Contains galactose and arabinose molecules. It has the property of a prebiotic, supports the normal balance of the microflora of the gastrointestinal tract. As a source of soluble dietary fiber, arabinogalactan improves nutrition, absorption and retention in a healthy state of the gastrointestinal tract and can be recommended as a nutraceutical or functional food Supplement in the daily diet. In addition, arabinogalactan contributes to the formation of short-chain fatty acids, which are extremely important for the normal functioning of the body. Arabinogalactan also has moisture-retaining properties and can be used to stabilize the purge [15].

The purpose of this study is to select the strain composition of starter cultures and study their influence and the effect of the biologically active additive Lavitol-B on the growth of microbial biomass, physical, chemical and organoleptic parameters of fermented milk products.

\section{Materials and methods}

In the course of experimental studies conducted in the laboratory of the Department of technology for processing agricultural products of the far Eastern GAU, two variants of starter cultures were used. The first variant consisted of the strains Str. thermophilus, Lactobacillus acidophilus and Bifidobacterium bifidum, the second variant-Str. 
thermophilus, Lactobacillus casei subsp. casei and Bifidobacterium bifidum with different ratios of strains- $1: 1: 1,3: 1: 1$ and $4: 1: 1$.

The following methods were used to determine the quality and safety of Lavitol-B premix on the basis of Ametis CJSC:

- humidity was determined according to GOST 16483.7-71;

- mass fraction of the dihydroquercetin and arabinogalactan according to the methods 24-10 and 70692152-7;

- presence of DDT, hexachlorocyclohexane, Aldrin and heptachlor according to MU 2142-80;

- mass fraction of mercury according to GOST 26927-86;

- mass fraction of arsenic according to GOST 31628-2012;

- mass fraction of lead according to MUC 4.1.986-00;

The mass fraction of cadmium according to GOST R 51301-99.

The number of mesophilic aerobic and facultative anaerobic microorganisms in the premix was determined according to GOST 10444.15-94 p. 6, bacteria of the coliform GOST 31747-2012 p. 9.1, pathogens, including Salmonella GOST 31659-2012 claim 8 and GOST 32010-2013 claim 8, yeast and molds according to GOST 10444.12-2013 p. 9 and E. coli according to GOST 30726-2001, p. 7.

In determining the chemical composition and properties of the obtained clots dairy products used the following methods:

- selection and preparation of samples was carried out according to GOST 26089-86,

- active acidity was determined on the Express milk analyzer pH-meter "HANNA" according to GOST 26781-85,

- titrated acidity was determined in accordance with GOST 3624-92,

- determination of the mass fraction of carbohydrates was carried out according to GOST 3626-73.

Organoleptic evaluation of the obtained samples of fermented milk products was performed in accordance with GOST R ISO 22935-2-2011 and GOST R ISO 22935-32011. The indicators of taste and smell, consistency were monitored.

Sampling for microbiological analysis was carried out in accordance with GOST 26668. cultivation of microorganisms for microbiological research was carried out in accordance with GOST 26670. The number of viable cells of lactic acid and bifidobacteria was established according to GOST 33951-2016 and GOST 32901-2014.

The number of bifidobacteria cells was determined by seeding in a hydrolysate-milk medium with temperature control of the crops for 24 hours at a temperature of $370 \mathrm{C}$.

Quantitative accounting of lactobacilli was performed on sterilized skim milk. The obtained results were reflected in colony-forming units (CFU), converting the conversion to $1 \mathrm{~g}$ of the studied samples and rounding up the experimental data in accordance with GOST 26670-90.

\section{Results}

It is known that the premix Lavitol-B is recommended to be applied in dry form to the milk prepared for fermentation. In this regard, the premix was investigated for quality and safety indicators. The data of the conducted research is presented in table 1.

Based on the data obtained, premix Lavitol-B meets the requirements of regulatory and technical documentation for this type of product and can be used in the production of fermented milk products.

The influence of the type and ratio of starter cultures on the fermentation process and the growth of microbial biomass with different ratios of starter cultures strains was 
established. The results of studies of two variants of starter cultures with different crop ratios are presented in table 2 .

Table 1. Quality and safety Analysis of Lavitol-B premix.

\begin{tabular}{|c|c|c|c|}
\hline № & Name of the indicator & Valid value & Analysis result \\
\hline 1 & Appearance & $\begin{array}{l}\text { Powder from white to pale } \\
\text { gray and pale cream color }\end{array}$ & $\begin{array}{l}\text { The powder is pale } \\
\text { creamy color }\end{array}$ \\
\hline 2 & Humidity, $\%$ & $<10.0$ & 5.30 \\
\hline 3 & $\begin{array}{l}\text { Mass fraction of dihydroquercetin, } \\
\%\end{array}$ & $>9.00$ & 24.30 \\
\hline 4 & $\begin{array}{l}\text { Mass fraction of arabinogalactan, } \\
\%\end{array}$ & $>75.00$ & 75.70 \\
\hline \multicolumn{4}{|c|}{ Quantitative and chemical analysis } \\
\hline 5 & DDT, $\mathrm{mg} / \mathrm{kg}$ & $<0.02$ & $<0.005$ \\
\hline 6 & $\begin{array}{l}\text { Hexachlorocyclohexane }(\mathrm{HCH}), \\
\mathrm{mg} / \mathrm{kg}\end{array}$ & $<0.50$ & $<0.005$ \\
\hline 7 & Andrin, $\mathrm{mg} / \mathrm{kg}$ & Not allowed & not detected \\
\hline 8 & Heptachlor, $\mathrm{mg} / \mathrm{kg}$ & Not allowed & not detected \\
\hline 9 & Mass fraction of mercury, $\mathrm{mg} / \mathrm{kg}$ & $<0.30$ & $<0.001$ \\
\hline 10 & Mass fraction of arsenic, $\mathrm{mg} / \mathrm{kg}$ & $<0.20$ & $<0.05$ \\
\hline 11 & Mass fraction of lead, $\mathrm{mg} / \mathrm{kg}$ & $<1.00$ & $<0.02$ \\
\hline 12 & Mass fraction of cadmium, $\mathrm{mg} / \mathrm{kg}$ & $<0.10$ & $<0.01$ \\
\hline \multicolumn{4}{|c|}{ Microbiological examination } \\
\hline 13 & $\begin{array}{l}\text { The number of mesophilic aerobic } \\
\text { and facultative anaerobic } \\
\text { microorganisms (QMAFAnM), } \\
\text { CFU/g }\end{array}$ & $<50000.00$ & $<40.00$ \\
\hline 14 & $\begin{array}{l}\text { Bacteria of group of intestinal } \\
\text { sticks (coliforms), including } \\
\text { coliforms in } 0.1 \mathrm{~g}\end{array}$ & Not allowed & not detected \\
\hline 15 & $\begin{array}{l}\text { Pathogenic microflora, including } \\
\text { Salmonella in } 25.0 \mathrm{~g}\end{array}$ & Not allowed & not detected \\
\hline 16 & Yeast and mold, CFU/g & $<100.00$ & $<10.00$ \\
\hline 17 & E. coli in $1.0 \mathrm{~g}$ & Not allowed & not detected \\
\hline
\end{tabular}

Table 2. Influence of the type and ratio of starter cultures on the fermentation process and growth of microbial biomass.

\begin{tabular}{|c|c|c|c|c|c|}
\hline \multirow{2}{*}{$\begin{array}{l}\text { Ratio of } \\
\text { starter } \\
\text { cultures }\end{array}$} & \multirow{2}{*}{$\begin{array}{l}\text { Active } \\
\text { acidity, } \\
\mathrm{pH}\end{array}$} & \multirow{2}{*}{$\begin{array}{l}\text { Titrated } \\
\text { acidity, }{ }^{0} \mathrm{~T}\end{array}$} & \multirow{2}{*}{$\begin{array}{c}\text { Duration of } \\
\text { fermentation, } \mathrm{h}\end{array}$} & \multicolumn{2}{|c|}{ Number of viable cells, CFU/g } \\
\hline & & & & $\begin{array}{c}\text { Lactic acid } \\
\text { microorganisms }\end{array}$ & Bifidobacteriums \\
\hline \multicolumn{6}{|c|}{1 option } \\
\hline $1: 1: 1$ & 4.2 & $66 \pm 2$ & $7.5 \pm 2$ & $4 * 10^{8}$ & $2 * 10^{7}$ \\
\hline $3: 1: 1$ & 4.5 & $71 \pm 2$ & $7.0 \pm 2$ & $6 * 10^{8}$ & $2 * 10^{8}$ \\
\hline $4: 1: 1$ & 4.8 & $75 \pm 2$ & $5.5 \pm 2$ & $3 * 10^{8}$ & $3 * 10^{8}$ \\
\hline \multicolumn{6}{|c|}{2 option } \\
\hline $1: 1: 1$ & 4.1 & $64 \pm 2$ & $8.5 \pm 2$ & $3 * 10^{8}$ & $6 * 10^{7}$ \\
\hline $3: 1: 1$ & 4.4 & $68 \pm 2$ & $7.5 \pm 2$ & $5 * 10^{8}$ & $3 * 10^{8}$ \\
\hline $4: 1: 1$ & 4.7 & $73 \pm 2$ & $6.0 \pm 2$ & $6 * 10^{8}$ & $5 * 10^{8}$ \\
\hline
\end{tabular}

When analyzing the data presented in table 1 , it can be seen that the ratio of microorganisms in the first starter 3:1:1 and 4:1:1 starter cultures of both variants showed the most intensive fermentation process, with an increase in the starter culture Str. thermophilus, which has the highest biochemical activity. When the ratio of microbial strains of the first option $3: 1: 1$ and $4: 1: 1$ and the second option $4: 1: 1$, there is an increase to 
a sufficient level of acidity for dairy products for 5.5-7 hours of fermentation. A less intense increase in acidity in the second version of the starter may be due to the presence of Lactobacillus casei subsp. casei, which does not have a high biochemical activity, while the fermentation process increases to an average of 10 hours. Uniform development of all microorganisms was observed in samples with a 4:1:1 ratio of cultures included in their composition. The acidity of the clot reaches $74 \pm 2^{0} \mathrm{~T}$ after 5.5 hours of fermentation.

Studies of the carbohydrate composition of clots obtained by fermenting milk containing $46 \%$ lactose using two types of starter cultures with different strain content. The data of the conducted studies are presented in table 3.

Table 3. Study of the carbohydrate composition of the obtained samples of fermented milk products depending on the type and ratio of starter cultures.

\begin{tabular}{|c|c|c|c|c|}
\hline \multirow{2}{*}{$\begin{array}{c}\text { Ratio of starter } \\
\text { cultures }\end{array}$} & \multicolumn{3}{|c|}{ Carbohydrate content in the test sample, $\%$} & \multirow{2}{*}{$\begin{array}{c}\text { Total } \\
\text { carbohydrate } \\
\text { content in the } \\
\text { sample, } \%\end{array}$} \\
\hline & Glucose & Lactose & Galactose & \\
\hline \multicolumn{5}{|c|}{1 option } \\
\hline $1: 1: 1$ & 1.840 & 0.001 & 1.453 & 3.294 \\
\hline $3: 1: 1$ & 0.812 & 1.220 & 1.175 & 3.207 \\
\hline $4: 1: 1$ & 0.001 & 3.352 & 0.089 & 3.442 \\
\hline \multicolumn{5}{|c|}{2 option } \\
\hline $1: 1: 1$ & 1.628 & 0.001 & 1.380 & 3.009 \\
\hline $3: 1: 1$ & 0.584 & 1.286 & 1.286 & 3.156 \\
\hline $4: 1: 1$ & 0.001 & 3.051 & 0.232 & 3.284 \\
\hline
\end{tabular}

Comparison of the carbohydrate composition of clusters obtained using the two choices of starter cultures, suggests the possibility of using abivariate of starter cultures at a ratio of microorganisms $3: 1: 1$ and $4: 1: 1$ for the production of therapeutic nutrition, since the total number of carbohydrates in the obtained samples of fermented milk products is $0.24 \%$, with up to $97 \pm 0.5 \%$ carbohydrates of the total number are made up of lactose, and $3 \pm 0.5 \%$ is represented by galactose, glucose content in the ratio of strains in the samples is negligible.

The influence of the selected ferment composition on the organoleptic characteristics of the product is shown in table 4.

Table 4. Organoleptic evaluation of the obtained samples of fermented milk products with the selected ratio of starter cultures.

\begin{tabular}{|c|c|c|}
\hline \multirow{2}{*}{ Ratio of starter cultures } & \multicolumn{2}{|c|}{ Organoleptic indicator } \\
\hline & Taste and smell & Consistency \\
\hline \multicolumn{3}{|c|}{1 option } \\
\hline $1: 1: 1$ & Weak fermented milk & A homogeneous, liquid \\
\hline $3: 1: 1$ & $\begin{array}{l}\text { Pure fermented milk with a slightly } \\
\text { pronounced aroma }\end{array}$ & $\begin{array}{l}\text { Homogeneous, moderately } \\
\text { viscous, weak clot }\end{array}$ \\
\hline $4: 1: 1$ & $\begin{array}{l}\text { Pure, fermented milk with a } \\
\text { pronounced aroma characteristic of } \\
\text { thermophilic Streptococcus and } \\
\text { acidophilus Bacillus }\end{array}$ & $\begin{array}{l}\text { A homogeneous, viscous, dense } \\
\text { clot }\end{array}$ \\
\hline \multicolumn{3}{|c|}{2 option } \\
\hline $1: 1: 1$ & Weak fermented milk & A homogeneous, liquid \\
\hline $3: 1: 1$ & $\begin{array}{l}\text { Pure fermented milk with a slightly } \\
\text { pronounced aroma }\end{array}$ & $\begin{array}{l}\text { Homogeneous, insufficiently } \\
\text { dense clot }\end{array}$ \\
\hline $4: 1: 1$ & $\begin{array}{l}\text { Pure, fermented milk with a } \\
\text { pronounced aroma characteristic of } \\
\text { thermophilic Streptococcus }\end{array}$ & Homogeneous, dense clot \\
\hline
\end{tabular}


Evaluating the organoleptic characteristics of the obtained fermented milk products developed using complex ferments, it was found that in all variants the taste and smell were pure, fermented milk. But with the ratio of starter cultures $4: 1: 1$, the organoleptic evaluation of the obtained samples had the highest score.

As a result of the obtained data, it is found that it is advisable to use 1 and 2 versions of the selected starter cultures with a ratio of $4: 1: 1$ strains.

When studying the effect of the Lavitol-B premix on the duration of the fermentation process and the intensity of development of lactic acid microorganisms, a complex starter culture was used in variants 1 and 2 with the ratio of strains: the first variant 4:1:1 - Str. thermophilus, Lactobacillus acidophilus and Bifidobacterium bifidum, the second variant 4:1:1 - Str. thermophilus, Lactobacillus casei subsp. casei and Bifidobacterium bifidum. The fermentation temperature was $42 \pm 2^{0} \mathrm{C}$. Samples of fermented milk products without the Lavitol-B premix were used as a control. The research results are shown in figures $1 \mathrm{a}$ and $1 \mathrm{~b}$.

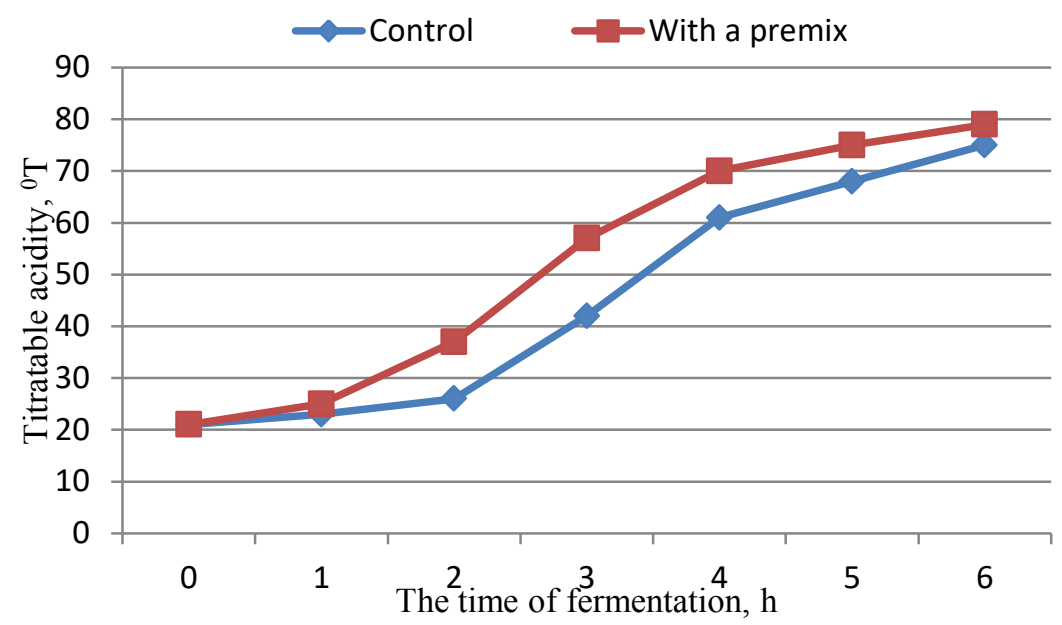

a) the first version of the starter

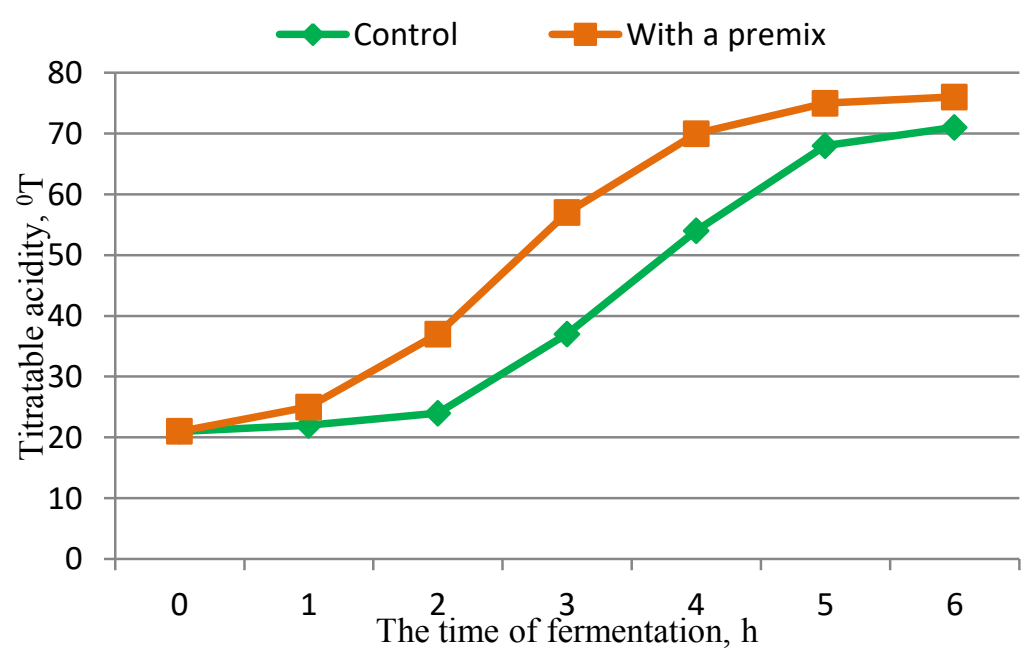

b) the second version of the starter

Fig. 1. Effect of premix on the fermentation process when using complex ferments. 
When applying the premix, the fermentation process with both versions of starter cultures went with a moderate increase in acidity and the highest organoleptic indicators were noted. Without the use of premix, the acidity in the model mixtures increased more slowly, while the taste and smell of the products were not sufficiently pronounced.

The effect of Lavitol-B premix on the intensity of lactic acid microorganisms development was studied. In experimental samples of fermented milk products. The research results are shown in figure 2.

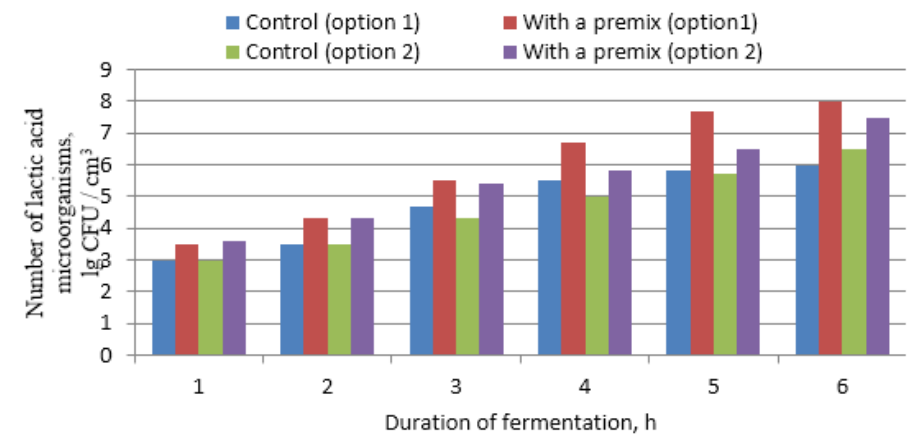

Fig. 2. Effect of the premix on the intensity of development of lactic acid microorganisms.

As can be seen from the data in figure 2, the number of lactic acid microorganisms in the samples with premix is higher than in the control samples, so in option 1 by $25.0 \%$ and in option 2 by $13.3 \%$.

\section{Discussion}

Analysis of the research shows that in the production of fermented milk products using selected complex ferments consisting of various strains of microorganisms at a certain ratio has improved organoleptic characteristics due to the use of an optimally selected ratio of microflora. The use of Lavitol-B premix, which is a natural antioxidant, shows the properties of a prebiotic and a complex starter, allows you to get a high-quality product with therapeutic and preventive properties.

\section{Conclusions}

In terms of quality and safety, premix Lavitol-B meets the requirements of regulatory and technical documentation and can be used in the production of fermented milk products.

The composition of a complex starter culture consisting of strains-the first variant of Str. thermophilus, Lactobacillus acidophilus and Bifidobacterium bifidum, the second variant-Str. thermophilus, Lactobacillus casei subsp. casei and Bifidobacterium bifidum. It was found that the ratio of microbial strains 4:1:1 in both versions of the starter culture has a high biochemical activity.

It is established that the premix Lavitol-B has prebiotic properties and contributes to the intensification of the production process of fermented milk products, which has a positive effect on the economic efficiency of production.

\section{References}

1. O.V. Pasko Molokosoderzhashchiye produkty s rastitelnym syryem, Molochnaya promyshlennost. 7, 40-41 (2009) 
2. V.A. Tutelyan, N.V Zhilinskaya,, V.A. Sarkisyan, A.A. Kochetkova, Analiz normativno-tekhnicheskoy bazy $\mathrm{v}$ sfere spetsializirovannoy pishchevoy produktsii $\mathrm{V}$ Rossiyskoy Federatsii Nutrition issues, 86(6), 29 - 35 (2017)

3. Terhi Aaltonen, Elina Kytö, SannaYlisjunttila-Huusko, Marko Outinen. Effect of the milk-based ash-protein ratio on the quality and acceptance of chocolate with a reduced sugar content, International Dairy Journal, 105, Article 104663 (2020)

4. Y. Ortiz-Rivera, R. Sánchez-Vega, N. Gutiérrez-Méndez, J. León-Félix, D. R. Sepulveda Production of reuterin in a fermented milk product by Lactobacillus reuteri: Inhibition of pathogens, spoilage microorganisms, and lactic acid bacteria, Journal of Dairy Science, 100, 4258-4268 (2017)

5. Antonella Bertazzo, Eugenio Ragazzi, Francesco Visioli. Evolution of tryptophan and its foremost metabolites' concentrations in milk and fermented dairyproducts. Pharma Nutrition, 4, 62-67 (2016)

6. Aline Pereira de Oliveira, Giselaine Alves dos Santos, Cassiana Seimi Nomura, Juliana Naozuka Elemental chemical composition of products derived from kefir fermented milk, Journal of Food Composition and Analysis, 7, 86-90 (2019)

7. P.A. Lisin, Ocenka nutrientnogo sostava jogurta obogashhennogo semenami chia Sbornik materialov Vserossijskoj (nacional'noj) nauchno-prakticheskoj konferencii posvjashhennoj 100-letiju so dnja rozhdenija S. I. Leont'eva. Omskij gosudarstvennyj agrarnyj universitet imeni P.A. Stolypina, 544-549 (2019)

8. E.A. Guz, E.G. Novitskaya, T.K. Kalenik, L.V. Levochkina, W. Piekoszewski The influence of vegetable puree containing carotenoids on the nutrient composition and structure of milk yoghurt, International journal of dairy technology, 1, 89-95 (2018)

9. E.A. Maruhina, L.M. Zaharova Tradicii v proizvodstve jogurtov Pererabotka moloka, 4 (222), 34-36 (2018)

10. I.S. Khamagayeva, , A.V. Schekotova, I.V. Khamaganova, Kislomolochnyy produkt, obogashchennyy zhelezom, Far Eastern Agrarian Bulletin 2(42), 132 - 138 (2017)

11. DanYang Li, Yan Zheng, Lai-yu Kwok, WenYi Zhang, TianSong Sun Metabolic footprinting revealed key biochemical changes in a brown fermented milk product usingStreptococcus thermophilus. Journal of Dairy Science, 103, 2128-2138 (2002)

12. A.P. Nechayev, Food chemistry: a textbook for university students trained in 552400 "Technology of food". 2nd edition, revised and corrected. St.Petersburg.: GIORD, 640 (2003)

13. S.L. Gribanova, Vestnik of the russian agricultural science, 2,58-61 (2019)

14. E.I. Reshetnik, Yu.I. Derzhapolskaya, [Development of technology for combined dairy products with prolonged shelf life] Kachestvo produktsii, tekhnologiy i oborudovaniya: sbornik trudov Mezhdunarodnoy nauchno-tekhnicheskoy konferentsii, Quality products, technologies and equipment: a collection of works of the International Scientific and Technical Conference, 82 - 85 (2007)

15. E.I. Reshetnik, Modifikacija tradicionnyh receptur kislomolochnyh produktov Materialy I Nacional'noj nauchno-tehnicheskoj konferencii s mezhdunarodnym uchastiem «Innovacionnye i resursosberegajushhie tehnologii produktov pitanija», jelektronnyj resurs - Izdatel'stvo: Astrahanskij gosudarstvennyj tehnicheskij universitet (Astrahan') (2018) 